Maja Klun

\title{
Performance Budgeting - the Slovenian Experience
}

UDK: 336.145(497.4)

\author{
Maja Klun \\ maja.klun@fu.uni-lj.si
}

\begin{abstract}
Reform processes in the public sector include measures leading to greater transparency in public spending, greater public accountability, and measurement of efficiency and effectiveness in the public sector. These measures include results-oriented budgeting, or a focus on results, or performance budgeting. This method of monitoring spending requires budget-spending units to set priorities and plan spending over the long term. The purpose of this paper is to define the concept and provide a brief presentation of various approaches to performance budgeting in practice abroad and the development of the budget process in Slovenia, measures relating to the implementation of performance budgeting, and the realisation of those measures.
\end{abstract}

Keywords: performance budgeting, Slovenia, budget process

JEL: $\quad$ Fiscal Policies and Behaviour of Economic Agents (H3), National Budget, Deficit and Debt (H6)

\section{Introduction}

Reform processes in the public sector include measures leading to greater transparency in public spending, greater public accountability, and measurement of efficiency and effectiveness in the public sector. These measures include results-oriented budgeting, or a focus on results, or performance budgeting ${ }^{1}$. Irrespective of the fact that this is an approach with a lengthy tradition (the concept is already at least 50 years old), in practice there

1 The equivalent term in Slovene (proračun na osnovi doseženih rezultatov) does not fully cover the meaning of the term 'performance budgeting', and would translate more closely to 'results-oriented budget' or the more commonly used 'output budgeting'. 
Maja Klun

Performance Budgeting - The Slovenian Experience

are still differing definitions of performance budgeting (PB). Practice in various countries has led to a whole range of approaches for PB implementation, emphasising various elements of a planned budget. Despite different definitions and approaches, the main objective of such planning is generally greater transparency, easier setting of public spending priorities, and greater support for efficient public sector management. This should lead to improved allocation of public funds and increase the operative efficiency of public spending. Economic classification of the budget alone does not offer sufficient information on what public funds are spent on. The PB approach demands better monitoring of public spending by purpose and programme, measuring results, setting objectives and indicators to measure the realisation of planned objectives and other PB measures shifting attention from individual public spending items (e.g. salaries) to work programmes, and the setting of strategies and their implementation. This therefore involves a closer link between public revenues, their use and the outputs achieved.

This method of monitoring spending requires budget-spending units to set priorities and plan spending over the long term. Under such an approach, if a budget-spending unit does not have clear objectives and strategies for a specific programme, it will not receive public funding. Preparation of specific objectives and the method of achieving them is therefore significant information in the allocation of public revenues. For senior planners of a proposed budget, this means that the use of allocated funds is justified by effective and efficient work.

The purpose of this paper is to define the PB concept, offer a brief presentation of different approaches to PB abroad and to identify any deficiencies. The paper also presents the development of the budget process in Slovenia and measures relating to $\mathrm{PB}$ implementation and the realisation of these measures.

\section{The PB concept}

The budgeting process has passed through various stages of development. The traditional form of budgeting entailed creating a draft budget based on past trends. Programme budgets require the preparation of spending plans for an individual work programme. Setting a budget in relation to objectives still entails preparing budgets by programme, but with an emphasis on the objec- 
Maja Klun

Performance Budgeting - The Slovenian Experience

tives that the budget-spending unit intends to achieve by implementing the programme. Zero-based budgeting means that funds are fully redefined each year or budget cycle, based on selected, quality programmes. Performance budgeting means that budget-spending units clearly define objectives, indicators, anticipated results, results reporting procedures and the relation of allocated funds to outputs. Due to the various approaches and definitions, different authors offer different summaries of PB. Osborne and Gaebler (1992) distinguish between output budgeting and outcome budgeting, while most authors use the term 'performance budgeting' and/or 'result-oriented budgeting' (Sterck and Scheers, 2006). Mayne (2008) considers that over the development of the budgeting process, emphasis was initially on outputs, before later turning towards outcomes. OECD (2007) states that various concepts and explanations of PB include results-oriented budgeting, budgeting focused on efficiency and effectiveness, financing based on efficiency and effectiveness measures, etc. OECD (2005) therefore offers a general definition of PB as a form of budget, within which the allocation of funds is linked to measurable results. Over $40 \%$ of OECD members began including non-financial information (primarily a combination of defining outputs and outcomes) in budget documents over a decade ago. The definition permits different models and approaches to PB and places them in three categories (OECD, 2007): presentational PB, performance-informed PB (i.e. informed of efficiency and effectiveness) and direct PB. The categories differ in how the link between financing and results is made, how results are forecast, and in the main purpose of the budgeting process. Presentational PB means that there is no link between financing and results; objectives and/or results are planned and the main purpose is public accountability. Performance-informed budgeting has only an indirect link between results and financing, with planning similar to that in presentational PB; the main purpose is planning and public accountability. Direct $\mathrm{PB}$ entails a direct link between funds and the results achieved; anticipated results are significant in the planning process and the main purpose is the allocation of public funds.

\section{PB and experience outside Slovenia}

There is no country that has a direct link between efficiency and effectiveness and the allocation of public funds for the entire budget. In general, the link is limited to specific sectors in a small number of countries IOECD and the 
Maja Klun

Performance Budgeting - The Slovenian Experience

World Bank, 2008). The OECD and World Bank analysis on the role of efficiency and effectiveness measurement in the budget process, which covers research in 97 countries in 2007, indicates that objective setting is present in $63.3 \%$ of countries ${ }^{2}$, while $66.7 \%$ use indicators, and $76.7 \%$ make use of reporting. Results $(80 \%)$ are used more than outcomes $(70 \%)$ in evaluation of efficiency and effectiveness throughout the surveyed countries. The majority of countries did not respond $(36.7 \%)$ or did not have $(16.7 \%)$ direct links in place between set objectives, indicators and planned funds. In most countries, the setting of objectives and indicators and reporting is focused on ministries, which do not generally use successful realisation of objectives or good indicator values in negotiations on allocation of funds. No country has cancelled a programme due to poor results, nor do responsible persons suffer negative consequences in the event of failure to achieve objectives or for poor results.

A review of PB implementation in the EU reveals similar conclusions to the above-mentioned research. The Member States which joined the EU in 2004 generally started to implement PB later on, after 2000. The Baltic states and Slovenia were among the first to start, followed by Slovakia, Romania and Bulgaria. In 2008, Poland received EU aid to implement a project (Robinson, 2008), which leaves only the Czech Republic to introduce PB in any form.

The introduction of non-financial efficiency and effectiveness indicators may serve different purposes (Krievins, 2007): as a tool for more transparent presentation of public spending, as support for planning public spending, as a means of reward and punishment or as a tool to communicate with the public.

Regardless of the level of PB implementation in an individual country, it still offers at least three major advantages (Kraan, 2008):

- closer links between the planning of work and anticipated results for an individual spending unit and the government's development strategy;

- long-term planning of spending and achieving set objectives;

- more realistic planning of spending, which requires realisation of results and outputs, improving the management of public funds;

- greater transparency for the public.

However, implementation of PB also brings certain problems. Pollitt (2001) states that these problems are due to different economic and political logic regard-

2 Different numbers of countries responded to each questions, so the percentages refer to the relevant sample. 
Maja Klun

Performance Budgeting - The Slovenian Experience

ing the achievement of the same objective. The problem, however, is wider than this. During the actual implementation of $\mathrm{PB}$, most countries face excessive measuring. This has led to too many objectives being set, with priority being given to setting objectives of interest to politicians as well as the wider public. Too little focus is therefore placed on the effects on society as a whole. Another problem that arose in practice was that budget-spending units began to perform actions that led to better indicator values and neglected actions that would also aid in achieving the objective. Measuring and evaluating efficiency and effectiveness requires permanent monitoring of the "usefulness" of indicators and their interpretation. The problem with $\mathrm{PB}$, particularly direct $\mathrm{PB}$, is in the budget cycles, which are short and do not permit measurement of outcomes, since a longer time period is generally needed for their evaluation (Aristigueta and Justice, 2006). The formation of a universal system that would entail an automatic link between results and the allocation of public funds should be avoided, since such systems do not permit new initiatives. This can also lead to incorrect allocations (Kraan, 2008).

A trend in the budget process has recently been noted towards monitoring budget-spending units in terms of business events rather than cash flows (Sterck and Scheers, 2006). This trend is partially the result of implementing $\mathrm{PB}$, since it has helped to achieve increased transparency of budget fund spending. Conversely, the European Commission (2008) is developing aggregate indicators to define the quality of public financing, combining financial and non-financial indicators.

Despite all the changes, the implementation of PB has not led to a reduction in public spending, since the structure of budgets, but not their function, has generally changed (Sterck, 2007).

\section{Slovenian experience with PB}

In defining PB, Slovenian legislation uses the terms "result-oriented budgeting" or "performance budgeting". Since independence, Slovenia has passed through a series of development stages of the budgeting process. In 1990-92, the concept of an integrated budget was introduced, a comprehensive tax reform was prepared, and the level of public debt defined. A second more important period, from 1993-99, saw the definition of budget execution rules, with revenue and expenditure classifications prepared, charts of accounts for 
Maja Klun

Performance Budgeting - The Slovenian Experience

public expenditure introduced, the level of public debt set and external control of budget-spending units introduced.

The most important period for PB was after 1999, when Slovenia began to adapt its budget system to EU rules. The adoption of the Public Finance Act (Official Gazette of the Republic of Slovenia, no 79/99; official Slovenian abbreviation: ZJF), which entered into force in the 2000 budget year, provided Slovenia with a programme classification and hence the basis for PB. In addition to the general section (balance of public finance revenues and expenses), a specific budget section was added, which includes the financial plans of direct budget-spending units (ZJF, Art. 10). The ZJF also defines the following mandatory content for explanations of budget-spending units' financial plans (ZJF, Art. 16):

- presentation of objectives, strategies and programmes in an individual area;

- legislative and other bases for the anticipated strategies and programmes;

- co-ordination of objectives, strategies and programmes with longterm development planning documents and budget memoranda;

- starting points and indicators on which calculations and assessments of required funds are based;

- other clarifications that enable an understanding of the proposed strategies and programmes;

- reporting on achieved objectives and results of strategies and programmes in the direct budget-spending unit's area of operation for the first half of the current year.

These elements of explanation of financial plans indicate a move towards $\mathrm{PB}$, since there is a need to define objectives, programmes, indicators, and reporting on the results achieved. These are the basic characteristics of PB, which the act itself defines. The introduction of PB after 2000 was also included in other implementing regulations and budget documents. For example, decrees on procedures for the preparation of the national budget were frequently amended with increasingly detailed definitions of the tasks of budgetspending units in the implementation of PB. The most recent decree was adopted in 2007 (the Decree on Development Planning Documentation and Preparation Procedures for the Draft National Budget and Self-Governing Local 
Community Budgets, OGRS, no 44/2007), which increased the resultmeasuring requirements compared with the ZJF. Article 41 states that the explanation of a draft financial plan must include the following mandatory elements: physical, financial and descriptive indicators to measure set objectives, and starting points and indicators on which calculations and assessments of required funds are based. Financial plans therefore present the proposed work programme and annual implementation plan.

The budget preparation manual for 2008 and 2009 (vol. 2) informs financial plan proposers that:

"... it is therefore very important that spending units state and clearly define objectives and related anticipated results, including indicators with which it will be possible to measure or verify the realisation of objectives at the end of the year ... Specific target values must be stated for each objective, as well as a schedule within which the objective will be achieved."

After 2000, Slovenia prepared an appropriate basis for PB via regulations. Instructions on the preparation of a final account for the national and municipal budgets were also adopted, as well as a methodology for preparing reports on the achievement of objectives and the results of direct and indirect budgetspending units. However, all these bases were insufficient to fully establish the concept in practice.

In its audit report on financial statements and the implementation of the national budget for 2001 and 2003, the Court of Auditors found that ministries were still not reporting with sufficient objectivity and transparency. In 2003, it was assessed that the situation had partly improved; however, the Court of Auditors still stated as its main reservation the inappropriate definition of financial plans, which did not contain sufficiently clear definitions of objectives and anticipated results for an individual programme in relation to the initial state in the field which the programme was intended to affect. Appropriate operational criteria and indicators with anticipated values were not defined for individual programmes, and this prevented assessment of an individual programme's success following implementation. Since the budget planning itself was deficient, the reporting was not focused on programme results and outputs. The Court of Auditors stated the situation remained similar in an audit in 2004.

In June 2005, the Ministry of Finance therefore submitted a Development Strategy for 2005-2008 for the Internal Control of Public Finances in the Republic 
Maja Klun

Performance Budgeting - The Slovenian Experience

of Slovenia to the government. The first objective of the Strategy focused on PB, since by 2008 all ministries were required to take PB into account in their planning, with main objectives clearly defined and anticipated outputs also defined in relation to the initial state in the field the programme was intended to affect. Objective assessment criteria were also to be defined. By 2008, the majority of each budget-spending unit's objectives were therefore supposed to be measurable, by means of appropriate indicators. A special expert group was formed to implement the objective (representatives of the Ministry of Finance, IMAD, the Court of Auditors, the Faculty of Administration of the University of Ljubljana, and an IMF representative). The main tasks were as follows:

- to analyse the current situation;

- to prepare detailed instructions and expert bases for PB-compliant planning of draft financial plans;

- to prepare appropriate training and to offer daily expert assistance in introducing the concept into the ministries;

- to report on the work performed.

The group first met in June 2005 and one of its first actions was to prepare new instructions on the formation of draft financial plans for budgetspending units. The instructions included detailed explanations of relevant terminology (output, result, input, objective, indicator, outcome, etc.) and appropriate instructions for the formation of objectives and indicators, together with practical examples. After the instructions had been drawn up, training workshops were organised for Ministry of Finance employees who were responsible for individual direct budget-spending units. Later, training was carried out for representatives with budget responsibilities from each ministry. Members of the group also offered individual consultations to select ministries (the Ministry of Agriculture, Forestry and Food, Ministry of Education and Sport, Ministry of the Environment and Spatial Planning, and the Ministry of Labour, Family and Social Affairs).

The audit report on the final accounts for the 2005 budget provided detailed analysis of the initial state. According to the findings, five ministries improved their planning compared to 2004; however, the average score for objective setting was still just $1.5^{3}$. The lowest score was for objective measurability (1.1), while the scores for level of explanation for requested budget

3 The score ranged from 1-5. 
funds (1.3) and reporting on outputs (1.5) were also low (Audit Report on Final Account of Slovenian 2005 and 2006 Budget). Furthermore, the established issue of failure to set objectives, to define indicators, initial and anticipated values, and failure to define actions was noted as a significant finding. The structuring of ministry sub-programmes was extremely diverse. Some were too complex and varied to allow overall objectives and hence indicators to be defined. Some sub-programmes were cost accounts which were therefore unsuitable for setting objectives and indicators (e.g. salaries).

At the group's proposal, in 2006 all ministries were required to re-evaluate the relevance of programme qualifications and the classification of budget items in individual sub-programmes and to prepare draft documents on the separation or combination and restructuring of sub-programmes to enable the definition of measurable, standardised objectives and indicators. Items within sub-programmes had to be as harmonised with actions or measures to achieve objectives as possible, while items whose influence on sub-programme function was difficult to assess were to be excluded. The expert group offered individual consultations at select ministries in the formation of some subprogrammes and their combination into rational groupings. General items were also defined as special sub-programmes.

The expert group concluded its work in early 2007. By that time, individual consultation and training had not yet been expanded to every ministry, so not every ministry had restructured its sub-programmes and analysis of set objectives and indicators. The group did not focus particular attention on reporting on outputs at the select ministries, and only suggested that ministries should follow the financial plan explanation as the basis for reporting, and that the report structure should match that set out in the proposal. During its brief period of operation (one budget cycle), the group did not succeed in developing mechanisms to link results and fund allocation, since most of its time was devoted to training and restructuring budget items for individual budgetspending units (Andoljšek et al., 2007). The Court of Auditors found in later audit reports that the greatest progress had been achieved in the group's selected ministries. The instructions for preparing financial plan proposals were later partially integrated into the Budget Manual.

In 2007, the Ministry of Finance formed a new, more narrowly defined group to address PB (a representative from the Faculty of Economics, representatives of the Ministry of Finance and Ministry of Transport, and an IMF 
Maja Klun

Performance Budgeting - The Slovenian Experience

representative). The group operated for one year, and its tasks were (Čok et al., 2008):

- to review work to date in Slovenia in the PB field;

- to identify programmes within the test ministries where PB could be first introduced (the Ministry of Finance, Ministry of Transport, and Ministry of Education and Sport were selected);

- to produce a case-study of parallel PB for the Tax Administration of the Republic of Slovenia, the Roads Directorate and the Primary Education programme within the Ministry of Education and Sport.

The group found in its final report that introducing PB to the Tax Administration would require the proposal of a functional structure for programmes that in general did not at that time match the organisational structure, that the existing information system did not support the functional monitoring of spending, and that the information system did not support automatic monitoring of realisation of objectives by means of indicators. At the Roads Directorate, it found that a series of actions would be required to ensure comprehensive measurement of objectives with indicators, including the aggregation of data and the creation of databases and analysis systems. Despite this, a new method of disclosure would make monitoring outputs simpler and make the functioning of the administration itself more efficient. The group did not carry out parallel PB at the Ministry of Education and Sport.

The report makes clear that the second group faced similar problems to the first, since one of the problems in implementing PB lies in the overburdening of staff at budget-spending units, who do not have individuals employed to carry out planning, reporting and monitoring, but require various employees to perform this work together alongside other ongoing duties. The group concluded its work with findings that generally matched those of the previous group (Čok et al., 2008):

- the consistent implementation of PB will require a commitment from the entire Slovenian government and one ministry will have to be appointed to lead the project;

- the PB concept entails a radical transformation in the understanding and implementation of the budgeting process and its implementation will last for several years; 


\section{Performance Budgeting - The Slovenian Experience}

- organisational changes will be required in a series of budget-spending users;

- specific funds must be linked to investment in information support;

- it would be rational to engage external experts in the project.

\section{Conclusion}

The legal basis for PB has been put in place in Slovenia and a range of actions to ensure the far-reaching introduction of PB have been implemented via the various expert groups. Regardless of this, Slovenia is still in the phase of defining objectives and indicators and on the creation of a method for reporting on programme realisation. Little has been done towards the evaluation of results, and less still towards linking results with planning or allocation of budget funds.

Some ministries have improved their definition of objectives and indicators each year. Despite this, the objective of "maintaining the ministry's work" is still found in financial plan explanations. Financial plan explanations still rarely define target values, a schedule for achieving planned objectives, or "initial" values. There is also greater emphasis in the national budget on results and less on outcomes. Budget-spending units' financial plan explanations give practically no links between objectives set, indicators, and proposed or planned funds.

Reporting on the realisation of objectives or results is less strong, since final account reports are often written in the future tense and links between the proposal and report are not usually clear, while links between results and funds used are rarer still.

Considerably more future effort will be required in the introduction of PB; in the near future, one probably cannot expect individual budget users to establish links between results and allocated public funds. 
Maja Klun

Performance Budgeting - The Slovenian Experience

Dr. Maja Klun is assistant professor at Faculty of Administration. Her main research fields are taxation, performance budgeting and performance measurement in public sector.

\section{Bibliography}

- $\quad$ Allwn, R. and Tommasi, D. (ed.) (2001): "Managing Public Expenditure - A Reference Book for Transition Countries", OECD Publishing, Paris.

- $\quad$ Andoljšek et al. (2007): "Zaključno poročilo o delu skupine za uvajanje k rezultatom usmerjenega proračuna", internal material.

- $\quad$ Aristigueta, M. P. and Justice, J. B. (2006): "The Status of Performance Budgeting", Public Performance \& Management Review, 30(1), pp. 7-13.

- Čok et al. (2008): “Poročilo o delu skupine za načrtovanje proračuna na osnovi doseženih rezultatov", internal material.

- European Commission (2008): "Developing Indicators for Assessing the Quality of Public Finances", European Commission, Brussels.

- Kraan, D.J. (2008): "Programme Budgeting in OECD Countries", OECD Journal on Budgeting, 7(4), pp. 7-47.

- Krievins, M. (2007): “Performance-Based Management Reforms: Good Practices and New Challenges", paper presented at Conference on Good Governance and Public Administration Reform.

- Mayne, J. (2007): "Challenges and Lessons in Implementing Results-Based Management", SAGE Publications, 13 (1), pp. 87-109.

- $\quad$ OECD (2005): "Modernising Government: The Way Forward", OECD Publishing, Paris.

- $\quad$ OECD (2007): "Performance budgeting in OECD countries", OECD Publishing, Paris.

- $\quad$ OECD and World Bank (2008): "International Budget Practices and Procedures Database", OECD Publishing: Paris.

- Osborne, T. and Gaebler, T. (1992): "Reinventing government: How the enterpreneurial spirit is transforming the public sector", Reading, Manchester. 
Maja Klun

\section{Performance Budgeting - The Slovenian Experience}

- Pollitt, C. (2001): "Integrating financial and performance management", OECD Journal on Budgeting, 1(2), pp. 7-37.

- Proračunski priročnik 2008-2009 (navodila za pripravo finančnih načrtov) - vol. 2, available at: http://www.gov.si/mf/slov/proracun/priprava_08_09/navodila_

proracun_07_08.htm\#prirocnik

- Revizijsko poročilo o predlogu zaključnega računa proračuna Republike Slovenije za leto 2005, available at: URL=http://www.rs-rs.si/rsrs/rsrs.nsf///K904A503D

78D89D5DC12571AF004EE9BA/\$file/IPro05-revizijsko-por.pdf

- Robinson, M. (2008): "Poland Pushes Ahead With Performance Budgeting", available at http://blog-pfm.imf.org/pfmblog/2008/10/poland-pushes-a.html

- $\quad$ Sterck, M. and Scheers, B. (2006): "Trends in Performance Budgeting in Seven OECD Countries", Public Performance \& Management Review, 30(1), pp. 47-72.

- Sterck, M. (2007): "The impact of performance budgeting on the role of the legislature: a four-country study", International Review of Administrative Sciences, 73(2), pp. 189203.

- Uredba o dokumentih razvojnega načrtovanja in postopkih za pripravo predloga državnega proračuna in proračunov samoupravnih lokalnih skupnosti, Official Gazette of the Republic of Slovenia, no 44/2007

- Zakon o javnih financah, OGRS, no 79/1999. 
Maja Klun

Performance Budgeting - The Slovenian Experience

POVZETEK

\section{K REZULTATOM USMERJENI PRORAČUN - IZKUŠNJE SLOVENIJE}

Reformni procesi javnega sektorja vključujejo ukrepe, ki vodijo k večji transparentnosti javne porabe, večji odgovornosti do javnosti in merjenje učinkovitosti in uspešnosti $v$ javnem sektorju. Del teh ukrepov je bil tudi $\mathrm{k}$ rezultatom usmerjeni proračun oz. naravnanost na rezultate oz. proračun na osnovi doseženih rezultatov (PB). OECD (2007) navaja, da različni pojmi in razlage $\mathrm{PB}$ vključujejo proračun usmerjen $\mathrm{k}$ rezultatom, proračun usmerjen na učinkovitost in uspešnost, financiranje na podlagi merjenja učinkovitosti in uspešnosti itd. Več kot $40 \%$ članic OECD je že pred več kot desetimi leti začelo $z$ vključevanjem nefinančnih informacij (predvsem kombinacijo določanja rezultatov in izidov) $v$ proračunske dokumente. Neposredna povezava med uspešnostjo in učinkovitostjo ter alokacijo javnih sredstev se za celotni proračun ne uporablja $v$ nobeni državi. Večinoma je povezava omejena zgolj na specifične sektorje $v$ manjšem številu držav (OECD in Svetovna banka, 2008). Podatki OECD in Svetovne banke o vlogi merjenja učinkovitosti in uspešnosti $v$ proračunskem procesu, ki zajemajo analizo raziskave v 97 državah za leto 2007, kažejo, da je določanje ciljev prisotno $\vee 63,3 \%$ držav $^{4}$, kazalnike uporablja $66,7 \%$, poročanje pa kar $76,7 \%$. V državah se za vrednotenje učinkovitosti in uspešnosti bolj uporabljajo rezultati ( $80 \%)$ kot izidi (70 \%). Večina držav ni odgovorila $(36,7 \%)$ ali pa nima $(16,7 \%)$ vzpostavljene neposredne povezanosti med zastavljenimi cilji, kazalniki in planiranimi sredstvi. Pregled uvajanja PB v EU prinaša podobne zaključke kot omenjena raziskava. Članice, ki so se priključile EU leta 2004, so večinoma začele z uvajanjem PB kasneje, in sicer po letu 2000. Med prvimi so bile baltiške države in Slovenija, sledile so Slovaška, Romunija in Bolgarija. Leta 2008 je Poljska prejela pomoč EU za izvedbo projekta (Robinson, 2008) in tako brez uvedbe PB ostaja samo Češka.

Po drugi strani uvajanje PB prinaša tudi določene težave. Pollitt (2001) navaja, da gre za težave zaradi različne ekonomske in politične logike o doseganju istega cilja. Vendar pa je problem širši. Pri samem uvajanju PB se je večina držav soočila s preobsežnim merjenjem. To je vodilo $v$ postavljanje prevelikega števila ciljev, prednostno so se postavljali cilji, ki so

$4 \mathrm{Na}$ vsako od vprašanj je odgovorilo različno število držav, zato se odstotki nanašajo na vzorec. 
Maja Klun

Performance Budgeting - The Slovenian Experience

zanimivi tako za politike kot širšo javnost. Premalo poudarka je bilo namenjenega učinkom na celotno družbo. Problem, ki se je ravno tako pokazal v praksi, je bil, da so začeli proračunski uporabniki opravljati tiste aktivnosti, ki so pripomogle $\mathrm{k}$ boljši vrednosti kazalnika in zanemarjale aktivnosti, ki bi tudi pripomogle k doseganju cilja. Problematika PB, predvsem neposrednega $\mathrm{PB}$, je $v$ proračunskih ciklih, ki so kratki in s tem ne omogočajo merjenje izidov, saj je za njihovo vrednotenje potrebno daljše časovno obdobje (Aristigueta in Justice, 2006).

Slovenska zakonodaja pri opredelitvi PB uporablja izraz k rezultatom usmerjeni proračun oz. proračun na osnovi doseženih rezultatov (PODR). Najpomembnejše obdobje za PODR je nastopilo po letu 1999, ko je Slovenija pričela proračunski sistem prilagajati pravilom Evropske Unije (EU). S sprejetjem Zakona o javnih financah (Ur. I. RS, št. 79/99, v nadaljevanju ZJF), ki je začel veljati s proračunskim letom 2000, je bila $v$ Sloveniji pripravljena programska klasifikacija in s tem podlaga za PODR. Slovenija je torej po letu 2000 pripravljala ustrezne podlage v predpisih. Sprejeti sta bili tudi navodilo o pripravi zaključnega računa državnega in občinskega proračuna ter metodologija za pripravo poročila o doseženih ciljih in rezultatih neposrednih in posrednih uporabnikov proračuna. Vendar vse te podlage niso bile dovolj, da bi obravnavani koncept zaživel $v$ praksi. Računsko sodišče je že $v$ revizijskih poročilih o izkazih in izvršitvi državnega proračuna za leti 2001 in 2003 ugotovilo, da ministrstva še vedno niso poročala dovolj objektivno in pregledno. Na podobno stanje je opozorilo računsko sodišče tudi $v$ reviziji za leto 2004.

Ministrstvo za finance je zato junija 2005 vladi $v$ ponovno potrditev posredovalo Strategijo razvoja notranjega nadzora javnih financ $v$ Republiki Sloveniji za obdobje od 2005 do 2008. Prvi cilj v Strategiji se osredotoča na PODR, saj naj bi do leta 2008 vsa ministrstva pri načrtovanju upoštevala načela k rezultatom usmerjenega proračuna, njihovi glavni cilji naj bi bili jasno opredeljeni, prav tako naj bi bili določeni tudi pričakovani dosežki glede na izhodiščno stanje na področju, na katerega s svojimi programi vplivajo. Določena naj bi bila merila za ocenjevanje doseganja ciljev. Za izvedbo cilja je bila oblikovana posebna skupina strokovnjakov (predstavniki Ministrstva za finance, Urada za makroekonomske analize in razvoj, Računskega sodišča, Fakultete za upravo in predstavnik Mednarodnega denarnega sklada (IMF)). Skupina se je prvič sestala že junija 2005 in ena izmed prvih aktivnosti je bila priprava novih navodil za oblikovanje predlogov finančnih načrtov proračunskih uporabnikov. Po oblikovanju 
Maja Klun

Performance Budgeting - The Slovenian Experience

navodil je bila najprej organizirana izobraževalna delavnica za zaposlene na Ministrstvu za finance (MF), ki so odgovorni za posamezne neposredne proračunske uporabnike. Kasneje je bilo izobraževanje izvedeno še za predstavnike s področja proračuna iz vsakega ministrstva. Člani skupine so na izbranih ministrstvih (ministrstvo za kmetijstvo, gozdarstvo in prehrano, ministrstvo za šolstvo in šport, ministrstvo za okolje in prostor in ministrstvo za delo, družino in socialne zadeve) izvedli individualno svetovanje. Strokovna skupina je zaključila svoje delo v začetku leta 2007. V tem času individualno svetovanje in izobraževanje ni bilo razširjeno na vsa ministrstva in zato ni prišlo do preoblikovanj podprogramov ter analiziranja postavljenih ciljev in kazalnikov na vseh ministrstvih. Leta 2007 je Ministrstvo za finance oblikovalo novo ožjo strokovno skupino, ki se je ukvarjala s PODR (predstavnik Ekonomske fakultete, predstavniki ministrstva za finance, ministrstva za promet in predstavnik Mednarodnega denarnega sklada). Skupina je delovala eno leto. Skupina je zaključila svoje delo z ugotovitvami, ki so večinoma skladne z ugotovitvami prejšnje skupine: za dosledno izvedbo PODR bi bila potrebna zaveza celotne vlade RS in določitev matičnega ministrstva, ki bi vodilo projekt, koncept PODR pomeni temeljit preobrat $v$ razumevanju in izvajanju proračunskega procesa in njegovo uvajanje bi trajalo nekaj let, potrebna bi bila organizacijska sprememba $v$ vrsti proračunskih uporabnikov, potrebna bi bila določena sredstva, povezana $z$ vlaganji $v$ informacijsko podporo, in smiselna bi bila pomoč zunanjih strokovnjakov. 